Review article

\title{
CANINE MONOCYTIC EHRLICHIOSIS: AN UPDATE ON DIAGNOSIS AND TREATMENT
}

\author{
MYLONAKIS Mathios E.*, THEODOROU Konstantina N. \\ Companion Animal Clinic, School of Veterinary Medicine, Faculty of Health Sciences, Aristotle \\ University of Thessaloniki, Thessaloniki, Greece
}

(Received 29 June, Accepted 13 July 2017)

Canine monocytic ehrlichiosis (CME) is a tick-borne disease of worldwide distribution. The major causative agent is Ebrlichia canis, a gram-negative, obligate intracellular, pleomorphic bacterium of the genus Ebrlichia, which infects monocytes, macrophages and lymphocytes, forming intracytoplasmic, membrane-bound bacterial aggregates, called morulae. After an incubation period of 8-20 days, the course of E. canis infection, can be sequentially divided into acute, subclinical and chronic phases, although these phases can hardly be distinguished in the clinical setting. Clinical recovery is the typical outcome of acutely infected dogs, entering the subclinical phase, during which they show no or minimal clinical signs and/or mild hematological abnormalities. Immunocompetent dogs may eliminate the infection during the acute or subclinical phases, but an unpredictable proportion of dogs will eventually develop the chronic phase, characterized by aplastic pancytopenia and high mortality, due to septicemia and/or severe bleeding. This article outlines briefly the pathogenesis of CME due to E. canis, and more thoroughly reviews the recent scientific literature pertaining to the diagnosis and treatment of this devastating disease.

Key words: Ehrlichia canis, Canine, Dog, Tick-borne Diseases

\section{INTRODUCTION}

Canine ehrlichiosis is caused by gram-negative, obligate intracellular, pleomorphic bacteria of the genus Ehrlichia (order Rickettsiales, family Anaplasmataceae). Ehrlichia spp. infect primarily leukocytes, forming intracytoplasmic, membrane-bound bacterial aggregates, called morulae [1]. At least five tick-transmitted Ehrlichia species have been documented to infect dogs, potentially causing the clinical disease $[1,2]$.

Ebrlichia canis was the first species recognized to infect dogs and is the principal cause of canine monocytic ehrlichiosis (CME) [1,3-4]. Ehrlichia chaffeensis, the cause of human monocytic ehrlichiosis, has recently emerged as an infrequent cause of clinical disease in the dog, indistinguishable from that caused by E. canis [5-7]. Ehrlichia ewingii,

\footnotetext{
*Corresponding author: e-mail: mmylonak@vet.auth.gr
} 
is the cause of canine granulocytic ehrlichiosis [5,8]. Ehrlichia ruminantium, the cause of heartwater in cattle, has been molecularly detected in the blood of healthy dogs or dogs presented with symptoms suggestive of ehrlichiosis, in the context of negative serological and molecular testing for E. canis [9]. Ehrlichia muris, has recently been identified in an ill dog from northern Minnesota that was seronegative to E. canis [10]. Recently, infection with Panola Mountain Ehrlichia sp. was documented in a clinically healthy dog with thrombocytopenia, atypical lymphocytes and T-cell expansion, which were resolved following doxycycline treatment [11].

Since the clinical importance and the bulk of scientific information pertaining to $E$. canis infection far outweigh those for the other canine ehrlichial infections, this article will briefly review the pathogenesis, and will emphasize on the diagnosis and treatment of E. canis-induced CME.

\section{PATHOGENESIS OF CME}

Ehrlichia canis is naturally transmitted transstadially and intrastadially, but not transovarially, by the tick Rhipicephalus sanguineous [1]. After an incubation period of 8-20 days, the course of E. canis infection, can be sequentially divided into acute (2-4 weeks), subclinical (several months to years) and chronic phases [2], but the distinction among these phases is not straightforward in the naturally-occurring disease. Clinical recovery is the typical outcome of acutely infected dogs, entering the subclinical phase, during which they show no or minimal clinical signs and/or mild hematological abnormalities [12-14]. Immunocompetent dogs may eliminate the infection during the acute or subclinical phases [5,12,15], but some will eventually develop the chronic phase, characterized by bone marrow (BM) aplasia, peripheral blood bi- or pancytopenia and high mortality due to septicemia and/or severe bleeding [16]. Occasionally, myelosuppression may develop soon after the recovery from the acute phase of the disease or without any prior signs of acute infection [16]. Therefore, the terms "non-myelosuppressive" and "myelosuppressive" CME, may better reflect the clinical severity of the disease, irrespective of its time progression [17]. The conditions that may precipitate the occurrence of myelosuppression have yet to be elucidated. Breed-specific susceptibility to the infection (German Shepherds seem to have higher morbidity and mortality compared to other breeds), coinfections with other vector-borne pathogens (e.g. Leishmania infantum, Anaplasma spp., Babesia spp., Rickettsia spp., Bartonella spp.), strain virulence or inoculum size variation, and the cytokine profile induced post-inoculation (i.e. high levels of INF- $\gamma$ have been associated with mild disease, as opposed to elevated IL-1 $\beta$ and IL- 8 ), may affect the clinicopathologic diversity and the outcome of CME [16-23]. While cellular immunity is pivotal for the protection against E. canis, the exuberant humoral response appears to confer no protection, and in fact may be detrimental to the host [24]. Several manifestations of the disease, including glomerulonephritis, uveitis, thrombocytopenia and anemia may have an immune-mediated pathogenetic component, as indicated by 
the presence of circulating immune-complexes, lymphocytic-plasmacytic infiltration of many parenchymal organs, polyclonal hyperglobulinemia, antiplatelet antibodies and the splenectomy-associated clinical and hematological improvement [25-30]. Bleeding tendency, the clinical hallmark of CME, is associated with impaired primary hemostasis due to thrombocytopenia, thrombocytopathy and mild vasculitis [16,3032]. Thrombocytopenia may be associated with immune-mediated platelet destruction, increased consumption secondary to mild vasculitis, splenic sequestration, overexpression of a platelet migration inhibition factor, BM failure in the myelosuppressive CME or a combination thereof $[16,26,29,30,33]$.

\section{DIAGNOSIS}

Diagnosis of CME is based on the integrated interpretation of history (living in or traveling to endemic areas, evidence of tick infestation), clinical and clinicopathologic compatibility and the results of the E. canis-specific testing.

\section{CLINICAL PRESENTATION}

Ehrlichia canis-induced disease ranges from mild (non-myelosuppressive) to lifethreatening (myelosuppressive) [30]. A percentage of experimentally-infected (and likely naturally infected dogs) will never exhibit clinical signs; on the other hand, in dogs living in endemic areas, coinfections with other vector-borne pathogens may complicate the diagnosis [5,6,22,34,35]. Fever (occasionally hypothermia in profoundly pancytopenic dogs), depression/lethargy, anorexia, lymphadenomegaly, splenomegaly, mucosal pallor, ocular abnormalities and bleeding tendency are typical clinical manifestations in the naturally-occurring disease [1,16,19,36-38]. Tick infestation may be seen, especially in the acute phase of the disease, while ulcerative stomatitis and necrotic glossitis, hind limb and/or scrotal edema, bacterial pyoderma, icterus and central nervous system signs such as seizures, ataxia, vestibular dysfunction and cervical pain, have been more frequently reported in chronic CME [16,38,39]. Bleeding diathesis is also more common and severe in the chronic phase of CME, and in those dogs with concurrent bleeding-predisposing conditions (e.g. infection with $L$. infantum, $A$. platys infection, von Willebrand's disease, drug-induced or uremic thrombocytopathy) $[38,40]$. It is manifested typically as cutaneous and mucosal petechiae and ecchymoses, hyphema, epistaxis, hematuria, melena, prolonged bleeding from venipuncture sites or intraoperative bleeding [16,19,40,41] (Figures 1-4). Ocular lesions are commonly seen in CME, and may be the sole presenting complaint. Anterior or posterior uveitis (Figure 3) is the most prevalent manifestation. Ocular discharge, blepharitis, conjunctivitis, corneal ulceration, painful necrotic scleritis, secondary glaucoma and retinal hemorrhage and/or detachment leading to blindness have also been reported [42-44]. Contrary to common belief, polyarthritis, manifested with lameness, joint swelling and stiff gait has yet to be documented in E. canis infection [45]. In subclinical 
CME the clinical manifestations are absent or they are mild and may go unnoticed by the owners (e.g. splenomegaly, intermittent fever) [14].

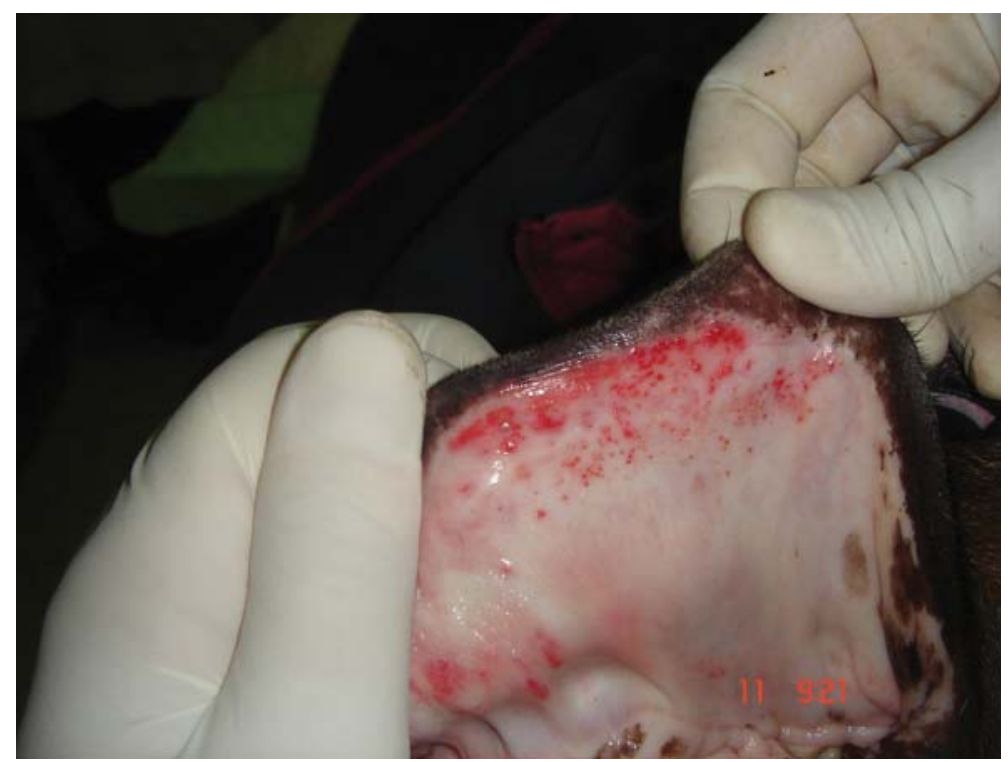

Figure 1. Numerous petechiae and ecchymoses on the upper lip mucosa from a dog with acute CME.

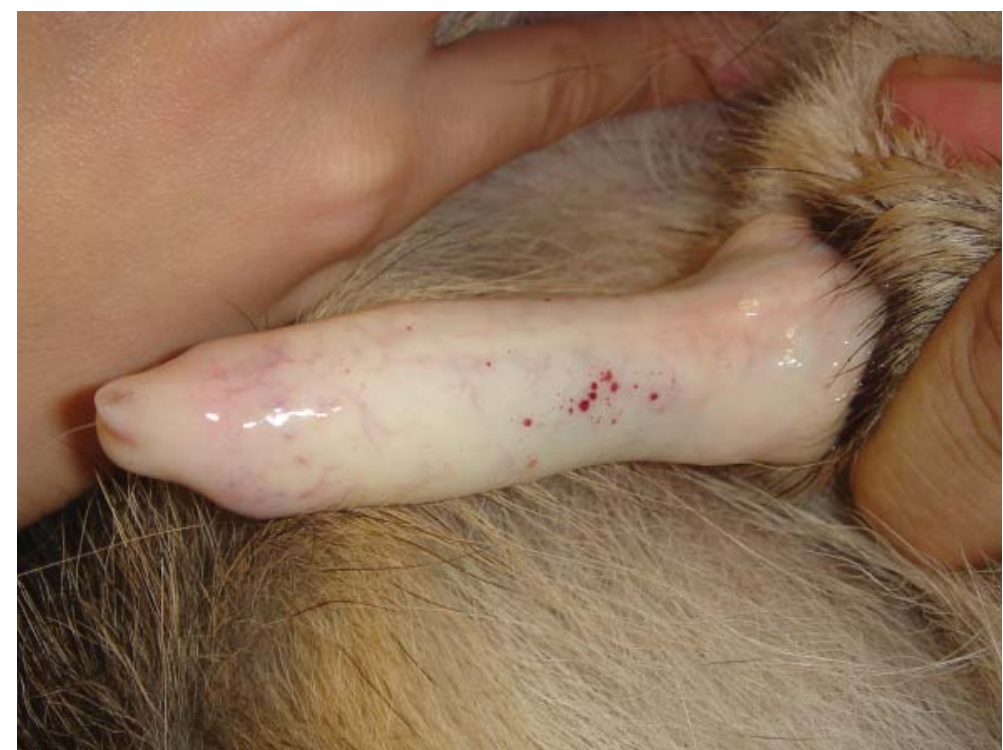

Figure 2. Penile mucosal pallor, petechiae and ecchymoses in a dog with CME-associated aplastic pancytopenia. 


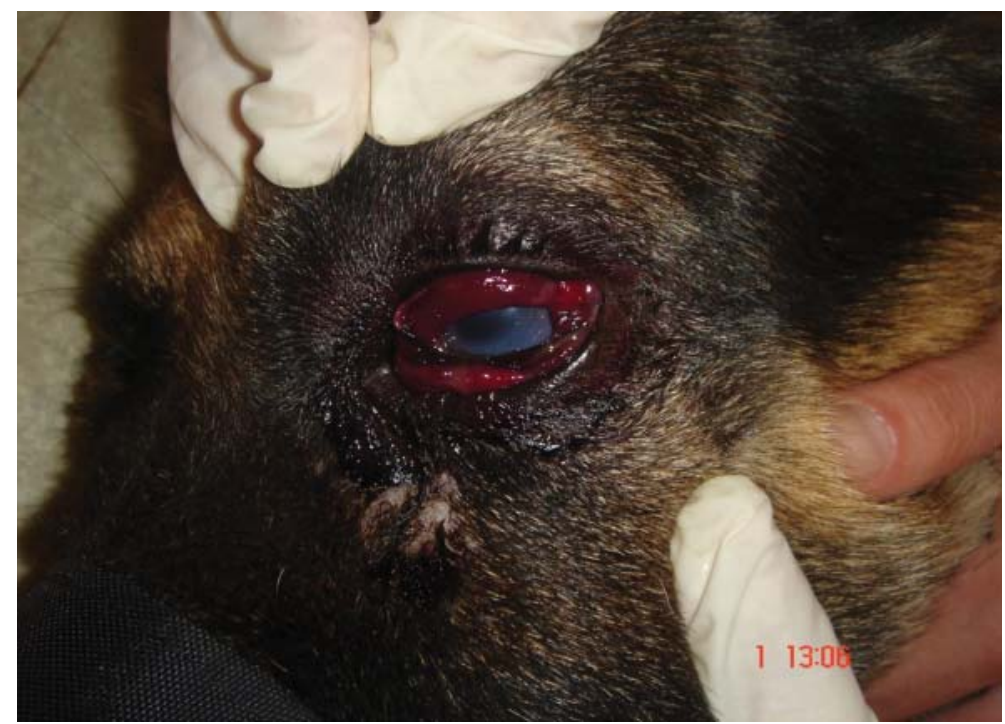

Figure 3. Conjunctival hemorrhage and anterior uveitis in a dog with CME.

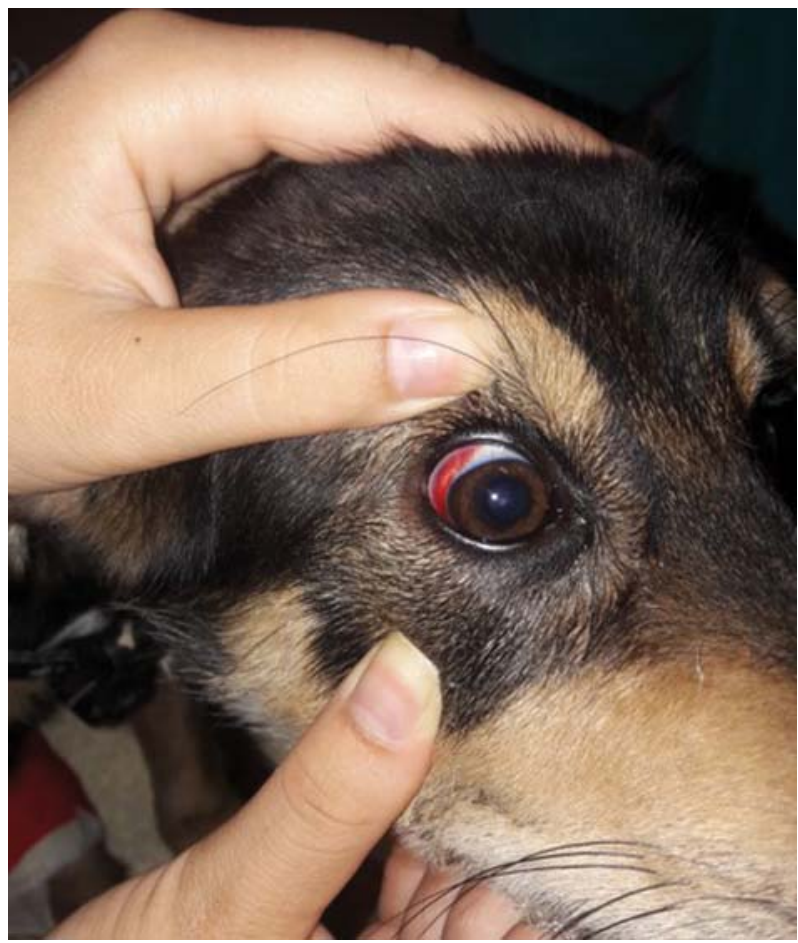

Figure 4. Scleral hemorrhage in a dog with CME.

\section{HEMATOLOGY}

Thrombocytopenia is the most frequent hematological abnormality in CME, appearing in more than $80 \%$ of the cases, regardless of the phase of the disease. However, CME 
should not be ruled out solely on the basis of a normal platelet count $[1,12,13,38]$. A non-regenerative anemia, leukopenia, neutropenia (mild-to-moderate leukocytosis / neutrophilia with or without a mild left shift may rarely be seen) and lymphopenia or mild lymphocytosis are additional abnormalities [32,46]. Granular lymphocytosis, with T-cell expansion in the blood and other tissues may occur in the subclinical and chronic phase of the disease, imitating lymphocytic leukemia (Figure 5) [11,47-50]. Thus, in endemic areas, CME should be a top differential for persistent lymphocytosis in the dog [49]. Aplastic pancytopenia typifies the myelosuppressive CME and the latter may be the major cause of canine pancytopenia in endemic areas [51]. Pancytopenia with normocellular BM may occur in acute CME, and is easily amenable to medical treatment [38]. A mild-to-moderate thrombocytopenia and/or anemia are the most consistent hematological findings in subclinical CME [13,52].

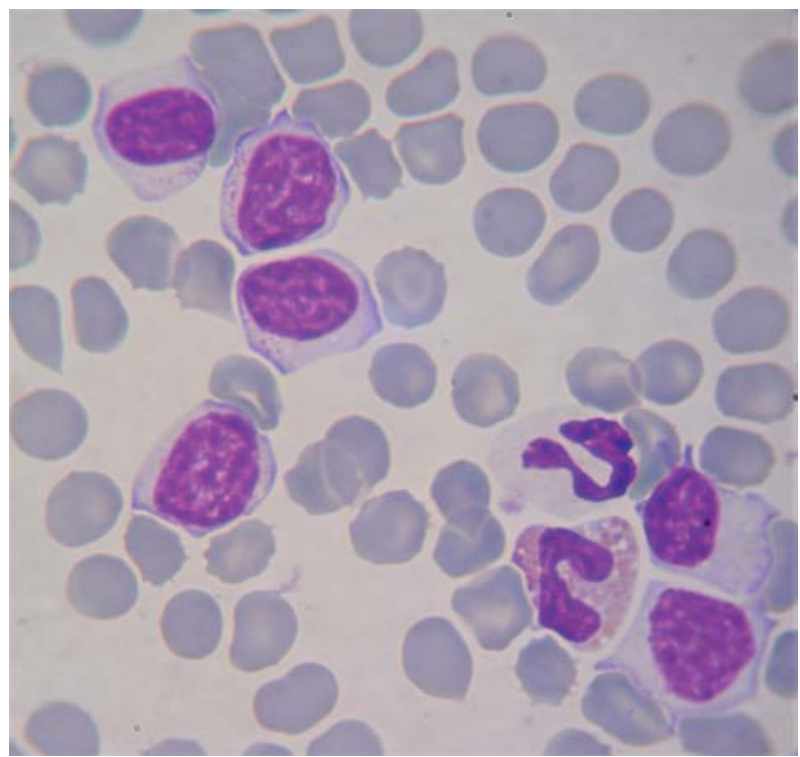

Figure 5. Blood smear from a dog with CME (Diff-Quik, objective 100x). The dog was presented with persistent mild lymphocytosis which resolved upon completion of the doxycycline treatment. Depicted are several granular lymphocytes and severe thrombocytopenia.

\section{BLOOD SERUM BIOCHEMISTRY}

Hyperproteinemia, hyperglobulinemia, hypoalbuminemia and mildly elevated alkaline phosphatase and alanin aminotransferase activities are common biochemical abnormalities in CME [13,36,38,53,54]. Hyperglobulinemia does not correlate with anti-E. canis IgG titers, and appears on serum electrophoresis to be caused by polyclonal or rarely, oligoclonal or monoclonal hypergammaglobulinemia $[33,36,48,53]$. Pancytopenic dogs tend to have lower total protein, total globulin and $\gamma$-globulin concentrations compared to their non-pancytopenic counterparts [53]. Liver disease may be primary or secondary to hypoxia, intrahepatic hemorrhage, or septicemia in the 
myelosuppressive CME [25,32,54]. Creatinine concentration is elevated in some dogs while glomerular proteinuria may be present, attributable to glomerulonephritis with or without immune-complexes deposition in the chronic and acute CME, respectively $[16,19,36]$.

Several reports indicate that in experimentally or naturally infected dogs, significant acute phase proteins and antioxidant responses may occur. C-reactive protein, haptoglobin, serum amyloid A, a1-acid glycoprotein and ferritin tend to increase (positive acute phase proteins), while albumin (negative acute phase protein) and paraoxonase-1 (oxidative stress indicator) tend to decrease [38,55-57] in dogs with acute and chronic, but not in the subclinical phase of the disease. However, the clinical relevance of these changes has yet to be fully appreciated. For instance, in a study with naturally occurring CME, the concentration of C-reactive protein, haptoglobin and serum amyloid $\mathrm{A}$ on admission were useful indicators of the clinical phase and severity of CME, but were not useful predictors of the clinical outcome [38]. In another study, they were of limited value as treatment response indicators in an experimental setting [57].

\section{CYTOLOGY}

Demonstration of Ehrlichia spp. morulae in monocytes, macrophages and lymphocytes (Figure 6) in Romanowsky-type stained smears from buffy coat and less frequently lymph node, BM, spleen, liver and cerebrospinal fluid smears, is helpful in establishing a definitive diagnosis of acute CME [2,54,58-62]. In a study with dogs naturallyinfected by $E$. canis (presumptive acute CME), the diagnostic sensitivity of buffy coat (review of 1000 oil immersion fields, 100x objective lens), lymph node (500 oil immersion fields, 100x objective lens) or their combination was $66 \%, 61 \%$ and $74 \%$, respectively [59]. In another study, diagnostic sensitivity of spleen cytology in dogs naturally infected by E. canis was 49\% [60]. Cytology may also support the diagnosis of CME even before seroconversion in acutely infected dogs and is valuable in documenting coinfections (e.g. Babesia spp., Hepatozoon canis, L. infantum), which may have therapeutic and prognostic implications [54]. On the other hand, cytology is a labor-intensive examination even in the acute phase of the disease (less than $1 \%$ infected mononuclear cells), it is notoriously insensitive in the subclinical and chronic $\mathrm{CME}$ and its specificity is adversely affected by the inability to identify the involved ehrlichial species and the fact that extraneous material such as phagocytosed platelets or nuclear remnants and lymphocytic azurophilic granules may imitate morulae [16,59].

Bone marrow cytology is also useful to differentiate the non-myelosuppressive from the myelosuppressive $\mathrm{CME}$, or to rule out other hematological syndromes causing pancytopenia (e.g. myelophthisis). Although BM histological biopsy is superior to cytology in appreciating the BM cellularity [63], review of at least 4 BM cytology smears correlates well with core biopsy in assessing BM cellularity in CME [64]. While in the acute CME BM appears to be normocellular, in the chronic CME a marked reduction 
of hematopoietic tissue is noticed, occupying less than $25 \%$ of the marrow flecks and usually consists of adipocytes, endothelial and stromal cells [16]. Occasionally, mildto-moderate mature mast cell and/or plasma cell hyperplasia may be seen and should not be confused with systemic mastocytosis or multiple myeloma, respectively [29].

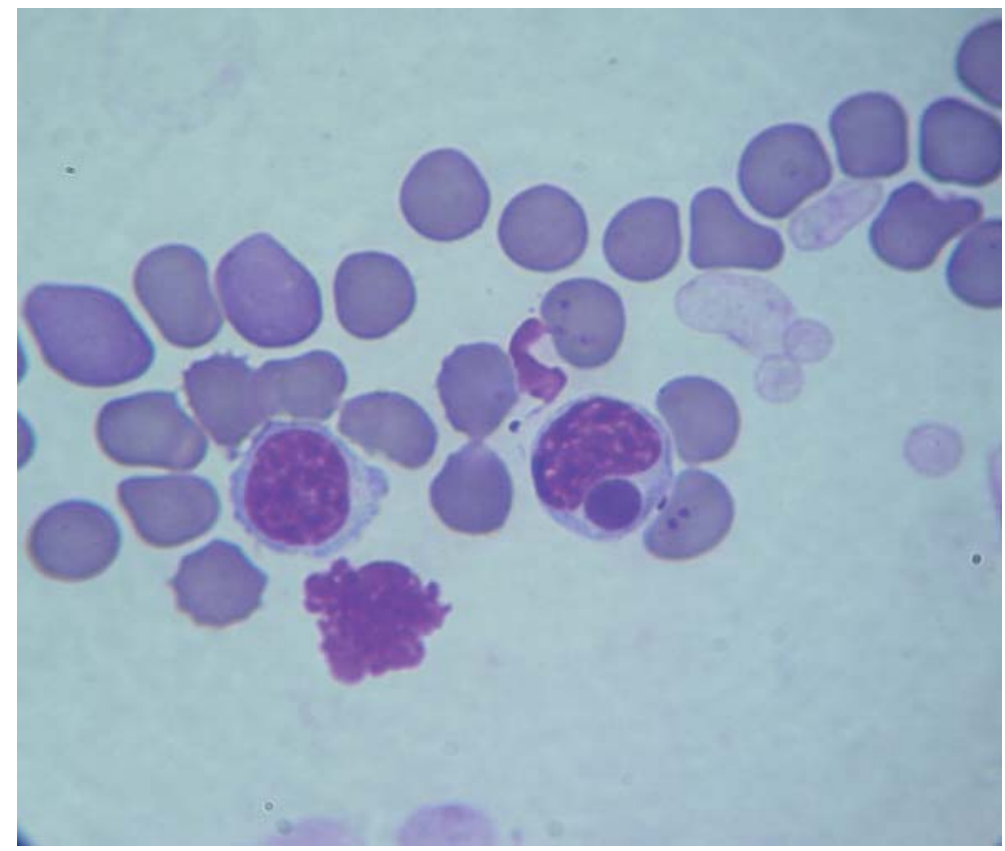

Figure 6. Buffy coat smear from a dog with experimental CME (Diff-Quik, objective 100x). An Ehrlichia canis morula is seen in a lymphocyte.

\section{SEROLOGY}

Serology is currently the mainstay for the confirmation of exposure to E. canis [62]. Indirect fluorescent antibody (IFA) testing is considered the "gold standard" for the detection and titration of anti-E. canis antibodies, although enzyme-linked immunosorbent assays (ELISA) are also used [65]. For most laboratories, an IgG titer equal to or greater than 1:80 is considered indicative of prior exposure to an Ehrlichia spp. Antibodies develop 7-35 days post-infection, and do not reliably correlate with the current carrier status, the duration of infection, or the presence and severity of clinical disease $[4,62,66,67]$. In experimental infections, $\operatorname{IgG}$ antibodies tend to increase earlier following intravenous (7-15 days) as compared to subcutaneous or intradermal inoculations (15-35 days) which may explain the variable intervals for seroconversion in the clinical setting $[68,69]$. Importantly, in acutely-infected dogs, clinical signs and hematological abnormalities may precede seroconversion $[22,54,65,66]$ and therefore, diagnosis of CME in an acutely ill patients should not be ruled out based on single time point serology alone. The demonstration of a four-fold seroconversion ( $\lg G)$ 
in paired serum samples obtained 2-3 weeks apart implies a recent infection [70]. Due to the prolonged subclinical phase and the persistent seropositivity following drug-mediated or self-eradication of the infection, the clinicians should be aware that seroreactivity to E. canis, especially in an endemic area, does not confirm that the clinical manifestations upon presentation are due to E. canis infection [70,71]. The kinetics of the IgM antibody titers is not predictable and it has currently limited clinical usefulness in CME [69]. The specificity of serology is also affected by the cross-reactivity that may occur among the same (i.e. E. canis, E. chaffeensis and E. ewingii), or, less likely, closely-related (i.e. A. phagocytophilum) genogroup species [62]. Although not routinely available, Western immunoblotting may distinguish between infections with Ehrlichia species that display cross-reactivity, while the chronicity of E. canis infection may be inferred based on immunoblot patterns [72,73]. Numerous in-house ELISA tests are commercially available for E. canis antibody testing. In general, these screening tests have been calibrated to become positive at an antibody level corresponding to an IFA titer of approximately 1:320 or higher; thus, a relatively low sensitivity may be anticipated, especially in acutely-infected dogs $[62,65,74]$.

\section{POLYMERASE CHAIN REACTION (PCR)}

Polymerase chain reaction may overcome several diagnostic limitations of serology (confirmation of exposure rather than current infection) and cytology (overall low diagnostic sensitivity). It is a highly sensitive method for the early detection (usually 4-10 days post-inoculation), molecular characterization and quantification (real-time PCR) of the ehrlichial organisms $[1,62,75,76]$. Also, PCR is more useful than serology, for the documentation of concurrent infections with different ehrlichial species and the post-treatment monitoring $[5,6,77,78]$. Importantly, in dogs with profound aplastic pancytopenia the diagnostic sensitivity of PCR may be suboptimal [16]. Several assays have been developed targeting an array of genes, such as the 16S rRNA or the p30 genes, to specifically detect E. canis infections in the dog [62]. The p30-based nested PCR assay may be more sensitive than the 16S rRNA-based nested PCR assay [75].

Successful amplification of Ehrlichia DNA may be accomplished from several tissues, including whole blood, BM, spleen, lymph nodes, liver, kidney, lung, and cerebrospinal fluid. If blood or other tissues are not available, PCR can be applied in residual serum samples [79]. In the naturally-occurring CME, the diagnostic sensitivity and the optimal tissue for PCR testing in the untreated dog or in the post-treatment setting have yet to be clarified. Two previous studies indicated that spleen specimens were of higher sensitivity compared to BM or blood for the confirmation of subclinical CME [52] and the evaluation of the response to treatment $[52,80]$. However, other studies, have suggested that the spleen was inferior to other tissues [40,71,77,81]. 


\section{TREATMENT}

In a dog with clinical and clinicopathologic manifestations consistent with CME in conjunction with the serological evidence of exposure to, and/or molecular or cytological evidence of E. canis infection, the decision for treatment is straightforward. The decision to treat a clinically healthy, seropositive dog may be particularly challenging, especially in endemic areas. A positive PCR result justifies E. canis-specific treatment. However, if PCR is negative, the proper course of action should be decided on a case-by-case basis. The authors incline towards treating these seropositive dogs if they have compatible clinicopathologic abnormalities (e.g. thrombocytopenia, hyperglobulinemia) with no evidence of other potential causes of these abnormalities [1].

Historically, doxycycline, a semi-synthetic tetracycline, has been the first-line drug for the treatment of CME. The consensus dosing recommendations for doxycycline in $\mathrm{CME}$ is $5 \mathrm{mg} / \mathrm{Kg}$, orally, twice daily, for at least 28 days [1,4]. Although doxycycline has been very effective in achieving clinical and/or clinicopathologic recovery in the vast majority of experimentally or naturally infected dogs experiencing acute or subclinical infections, it has not been invariably effective in eliminating E. canis infection $[14,15,22,24,77,78,80,82-85]$. For example, in a recent experimental study, the efficacy of the consensus doxycycline regimen was investigated during acute, subclinical and chronic CME. Despite the clinical and hematologic recovery of the dogs and the negative blood PCR in the majority of treated dogs, $R$ sanguineus ticks fed on the dogs after doxycycline treatment (xenodiagnosis) became PCR-positive for E. canis DNA, regardless of the phase treatment was instituted; similarly, most of the naïve dogs inoculated with pooled blood from the treated dogs became PCR positive [85]. These results may imply that E. canis infection may persist even following prolonged doxycycline treatment. Doxycycline is also ineffective in dogs with profound aplastic pancytopenia complicated with septicemia and severe bleeding [16]. Some dogs may experience nausea and vomiting with oral doxycycline, which may be mitigated by mixing the drug with food [86].

There is currently limited evidence-based justification for using other tetracyclines (minocycline, tetracycline, oxytetracycline) or chloramphenicol, while enrofloxacin, azithromycin and imidocarb dipropionate have been found ineffective in achieving clinical and hematologic remission or in clearing the infection [87-89]. Therefore, imidocarb dipropionate is no longer indicated in CME, except in dual infections with Babesia canis [1,88]. Rifampicin, an inhibitor of the B subunit of DNA-dependent RNA polymerase, has recently received attention as a potential alternative drug to doxycycline. In an in vitro study on antibiotic susceptibilities, rifampicin was as effective as doxycycline against E. canis [90]. When rifampicin was given $(15 \mathrm{mg} / \mathrm{kg} / 12 \mathrm{~h}$ orally for 7 days) to two subclinically infected, moderately pancytopenic dogs, pancytopenia was resolved and E. canis DNA was cleared from the blood, as documented by PCR [84]. The same rifampicin regimen, given to two asymptomatic E. canis-infected dogs 
700 days post-inoculation, after an ineffective course with doxycycline, appeared to clear the infection in one of the two dogs, based on xenodiagnosis with ticks [85]. Finally, it was recently shown in an experimental setting that rifampicin $(10 \mathrm{mg} /$ $\mathrm{Kg}$, once daily, orally, for 21 days) was partially effective in eliminating acute E. canis infection, but it objectively hastened hematologic recovery as opposed to infected untreated dogs [71]. Provided that the safety profile of rifampicin in the dog will be sufficiently refined [91], it might be a promising alternative to doxycycline in CME, as the clinical experience in human ehrlichiosis currently suggests [92,93].

A short-term glucocorticoid treatment (1-2 mg/ $\mathrm{Kg}$, daily, for one week), has been advocated in CME for attenuating the immune-mediated component of the disease manifestations. In the authors' opinion, this is very rarely needed, since rapid improvement is noticed soon after the institution of doxycycline treatment in acutelyinfected dogs [22]; on the other hand, the administration of glucococorticoids in a profoundly leukopenic dog, may exacerbate the disease [37].

In dogs with CME-induced aplastic pancytopenia, supportive treatment is critically important if the limited chances for survival are to be pursued. It includes the administration of balanced crystalloid solutions and/or the periodic blood-typed and cross-matched packed red blood cells or whole blood transfusions, and prophylactic (asymptomatic dogs with moderate-to-severe neutropenia (neutrophil count $<1,000$ / $\mu \mathrm{l})$ ) or therapeutic (symptomatic neutropenic dogs) use of bactericidal antibiotics [94].

\section{POST-TREATMENT MONITORING}

Post-treatment monitoring is particularly important in E. canis infections. Unlike the myelosuppressive CME which is refractory to treatment, acutely-infected dogs, experience a rapid clinical improvement within 24-48 hours from treatment initiation, while resolution of hematologic abnormalities takes 1-3 weeks [24,71,80]. Failure of the dog to respond in the aforementioned time frame should prompt the clinician to reconsider the diagnosis; on the other hand, clinical and hematologic recovery may precede the elimination of $E$. canis, thus, treatment should not be terminated based on the clinical and hematologic normalization alone [80]. Reappearance of thrombocytopenia 2-4 weeks after the cessation of doxycycline indicates treatment failure or re-infection [87]. Hyperglobulinemia tends to resolve 6-9 months after the initiation of treatment, and persistent hyperglobulinemia may indicate treatment failure or concurrent infectious or neoplastic conditions. The kinetics of $\operatorname{IgG}$ antibodies is unpredictable, frequently persisting several months to years following eradication of the organism, which minimizes the value of serology as a post-treatment monitoring tool $[70,71,78,87]$. In this respect, PCR applied in the blood, BM and spleen aspirates, 4-8 weeks after the completion of treatment, is the most reliable method in the clinical setting to prove the clearance of E. canis infection [14,35,71]. Prognosis is good to excellent in the acute or subclinical CME. Profound pancytopenia, severe leukopenia or neutropenia and severe anemia, herald a grave prognosis [38]. 


\section{PREVENTION}

Dogs that have recovered and cleared of the infection do not acquire permanent immunity and may become re-infected [24]. Therefore, tick control with careful manual removal or by applying appropriate acaricides on a year-round basis, is the single most important measure for the prevention of E. canis infection. Importantly, it was recently shown that E. canis transmission may start a few (3-8) hours after tick attachment [95]. Tick control products such as those containing phenylpyrazoles (pyriprol, fipronil), pyrethroids (permethrin, deltamethrin, tetramethrin, flumethrin), amitraz and isoxazolines (fluralaner, sarolaner, afoxolaner) have been shown to be very effective in reducing the incidence of E. canis infection and/or tick infestation, but the owners should be aware that no product can completely prevent the infection in all dogs, under all circumstances [96-98]. In highly endemic areas, when adequate tick control is hard to achieve, prophylactic daily use of low dose doxycycline during the tick season, reduces the risk of infection [99], although this practice may promote drug resistance. Incoming dogs in a non-endemic area should be serologically screened and treated accordingly.

\section{Authors' contributions}

MM was the main author of the manuscript. TK has helped to draft the manuscript. Both authors read and approved the final manuscript.

\section{Declaration of conflicting interests}

The author(s) declared no potential conflicts of interest with respect to the research, authorship, and/or publication of this article.

\section{REFERENCES}

1. Sainz A, Roura X, Miro G, Estrada-Pena A, Kohn B, Harrus S, Solano-Gallego L. Guidelines for veterinary practitioners on canine ehrlichiosis and anaplasmosis in Europe. Parasit \& Vectors 2015,8:75.

2. Harrus S, Waner T, Neer M: Ehrlichia canis infection. In: Infectious Diseases of the Dog and Cat. St. Louis, Missouri: Elsevier Saunders; 2012, 227-238.

3. Donatien A, Lestoguard F. Existence en Algerie d'un Rickettsia du chien. Bull Soc Pathol Exot 1935,28:418-419.

4. Neer TM, Breitschwerdt EB, Greene RT, Lappin MR. Consensus statement on ehrlichial disease of small animals from the infectious disease study group of the ACVIM. American College of Veterinary Internal Medicine. J Vet Intern Med 2002,16:309-315.

5. Breitschwerdt EB, Hegarty BC, Hancock SI. Sequential evaluation of dogs naturally infected with Ehrlichia canis, Ehrlichia chaffeensis, Ehrlichia equi, Ehrlichia ewingii, or Bartonella vinsonii. J Clin Microbiol 1998,36:2645-2651. 
6. Kordick SK, Breitschwerdt EB, Hegarty BC, Southwick KL, Colitz CM, Hancock SI, Bradley JM, Rumbough R, McPherson JT, MacCormack JN. Coinfection with multiple tick-borne pathogens in a Walker Hound kennel in North Carolina. J Clin Microbiol 1999,37:2631-2638.

7. Nair AD, Cheng C, Ganta CK, Sanderson MW, Alleman AR, Munderloh UG, Ganta RR. Comparative experimental infection study in dogs with Ehrlichia canis, E. chaffeensis, Anaplasma platys and A. phagocytophilum. PLoS One 2016,11:e0148239.

8. Goodman RA, Hawkins EC, Olby NJ, Grindem CB, Hegarty B, Breitschwerdt EB. Molecular identification of Ehrlichia ewingii infection in dogs: 15 cases (1997-2001). J Am Vet Med Assoc 2003,222:1102-1107.

9. Allsopp MT, Allsopp BA. Novel Ehrlichia genotype detected in dogs in South Africa. J Clin Microbiol 2001,39:4204-4207.

10. Hegarty BC, Maggi RG, Koskinen P, Beall MJ, Eberts M, Chandrashekar R, Breitschwerdt EB. Ehrlichia muris infection in a dog from Minnesota. J Vet Intern Med 2012,26:1217-1220.

11. Qurollo BA, Davenport AC, Sherbert BM, Grindem CB, Birkenheuer AJ, Breitschwerdt EB. Infection with Panola Mountain Ehrlichia sp. in a dog with atypical lymphocytes and clonal T-cell expansion. J Vet Intern Med 2013,27:1251-1255.

12. Codner EC, Farris-Smith LL. Characterization of the subclinical phase of ehrlichiosis in dogs. J Am Vet Med Assoc 1986,189:47-50.

13. Waner T, Harrus S, Bark H, Bogin E, Avidar Y, Keysary A. Characterization of the subclinical phase of canine ehrlichiosis in experimentally infected beagle dogs. Vet Parasitol 1997,69:307-317.

14. Fourie JJ, Horak I, Crafford D, Erasmus HL, Botha OJ. The efficacy of a generic doxycycline tablet in the treatment of canine monocytic ehrlichiosis. J S Afr Vet Assoc 2015,86:1193.

15. Harrus S, Waner T, Aizenberg I, Bark H. Therapeutic effect of doxycycline in experimental subclinical canine monocytic ehrlichiosis: evaluation of a 6-week course. J Clin Microbiol 1998,36:2140-2142.

16. Mylonakis ME, Koutinas AF, Breitscwerdt EB, Hegarty BC, Billinis CD, Leontides LS, Kontos VS. Chronic canine ehrlichiosis (Ehrlichia canis): a retrospective study of 19 natural cases. J Am Anim Hosp Assoc 2004,40:174-184.

17. Siarkou VI, Mylonakis ME, Bourtzi-Hatzopoulou E, Koutinas AF. Sequence and phylogenetic analysis of the 16S rRNA gene of Ehrlichia canis strains in dogs with clinical monocytic ehrlichiosis. Vet Microbiol 2007,125:304-312.

18. Nyindo M, Huxsoll DL, Ristic M, Kakoma I, Brown JL, Carson CA, Stephenson EH. Cell-mediated and humoral immune responses of German Shepherd Dogs and Beagles to experimental infection with Ehrlichia canis. Am J Vet Res 1980,41:250-254.

19. Harrus S, Kass PH, Klement E, Waner T. Canine monocytic ehrlichiosis: a retrospective study of 100 cases, and an eepidemiological investigation of prognostic indicators for the disease. Vet Rec 1997,4:360-363.

20. Tajima T, Rikihisa Y. Cytokine responses in dogs infected with Ehrlichia canis Oklahoma strain. Ann N Y Acad Sci 2005,1063:429-432.

21. Unver A, Huang H, Rikihisa Y. Cytokine gene expression by peripheral blood leukocytes in dogs experimentally infected with a new virulent strain of Ehrlichia canis. Ann N Y Acad Sci 2006,1078:482-486. 
22. Gaunt S, Beall M, Stillman B, Lorentzen L, Diniz P, Chandrashekar R, Breitschwerdt E. Experimental infection and co-infection of dogs with Anaplasma platys and Ehrlichia canis: hematologic, serologic and molecular findings. Parasit Vectors 2010,3:33.

23. Day MJ. The immunopathology of canine vector-borne diseases. Parasit Vectors 2011,4:48.

24. Breitschwerdt EB, Hegarty BC, Hancock SI. Doxycycline hyclate treatment of experimental canine ehrlichiosis followed by challenge inoculation with two Ehrlichia canis strains. Antimicrob Agents Chemother 1998,42:362-368.

25. Hildebrandt PK, Huxsoll DL, Walker JS, Nims RM, Taylor R, Andrews M. Pathology of canine ehrlichiosis (tropical canine pancytopenia). Am J Vet Res 1973,34:1309-1320.

26. Harrus S, Waner T, Weiss DJ, Keysary A, Bark H. Kinetics of serum antiplatelet antibodies in experimental acute canine ehrlichiosis. Vet Immunol Immunopathol 1996,51:13-20.

27. Harrus S, Waner T, Keysary A, Aroch I, Voet H, Bark H. Investigation of splenic functions in canine monocytic ehrlichiosis. Vet Immunol Immunopathol 1998,62:15-27.

28. Waner T, Leykin I, Shinitsky M, Sharabani E, Buch H, Keysary A, Bark H, Harrus S. Detection of platelet-bound antibodies in beagle dogs after artificial infection with Ehrlichia canis. Vet Immunol Immunopathol 2000,77:145-150.

29. Mylonakis ME, Koutinas AF, Leontides LS. Bone marrow mastocytosis in dogs with myelosuppressive monocytic ehrlichiosis (Ehrlichia canis): a retrospective study. Vet Clin Pathol 2006,35:311-314.

30. Waner'T, Harrus S. Canine monocytic ehrlichiosis: from pathology to clinical manifestations. Isr J Vet Med 2013,68:12-18.

31. Harrus S, Waner T, Eldor A, Zwang E, Bark H. Platelet dysfunction associated with experimental acute canine ehrlichiosis. Vet Rec 1996,139:290-293.

32. De Castro MB, Machado RZ, de Aquino LP, Alessi AC, Costa MT. Experimental acute canine monocytic ehrlichiosis: clinicopathological and immunopathological findings. Vet Parasitol 2004,119:73-86.

33. Harrus S, Ofri R, Aizenberg I, Waner T. Acute blindness associated with monoclonal gammopathy induced by Ehrlichia canis infection. Vet Parasitol 1998,78:155-160.

34. Mekuzas Y, Gradoni L, Oliva G, Foglia Manzillo V, Baneth G. Ehrlichia canis and Leishmania infantum co-infection: a 3-year longitudinal study in naturally exposed dogs. Clin Microbiol Infect Suppl 2009,2:30-31.

35. De Tommasi AS, Otranto D, Dantas-Torres F, Capelli G, Breitschwerdt EB, De Caprariis D. Are vector-borne pathogen co-infections complicating the clinical presentation in dogs? Parasit Vectors 2013,6:97

36. Frank JR, Breitschwerdt EB. A retrospective study of ehrlichiosis in 62 dogs from North Carolina and Virginia. J Vet Intern Med 1999,13:194-201.

37. Shipov A, Klement E, Reuveni-Tager L, Waner T, Harrus S. Prognostic indicators for canine monocytic ehrlichiosis. Vet Parasitol 2008,153:131-138.

38. Mylonakis ME, Ceron JJ, Leontides L, Siarkou VI, Martinez S, Tvarijonaviciute A, Koutinas AF, Harrus S. Serum acute phase proteins as clinical phase indicators and outcome predictors in naturally occurring canine monocytic ehrlichiosis. J Vet Intern Med 2011,25:811-817.

39. Kaewmongkol G, Maneesaay P, Suwanna N, Tiraphut B, Krajarngjang T, Chouybumrung A, Kaewmongkol S, Sirinarumitr T, Jittapalapong S, Fenwick SG. First Detection of Ehrlichia canis in cerebrospinal fluid from a nonthrombocytopenic dog with meningoencephalitis by broad-range PCR. J Vet Intern Med 2016,30:255-259. 
40. Lanza-Perea M, Zieger U, Qurollo BA, Hegarty BC, Pultorak EL, Kumthekar S, BruhlDay R, Breitschwerdt EB. Intraoperative bleeding in dogs from Grenada seroreactive to Anaplasma platys and Ehrlichia canis. J Vet Intern Med 2014,28:1702-1707.

41. Mylonakis ME, Saridomichelakis MN, Lazaridis V, Leontides LS, Kostoulas P, Koutinas AF. A retrospective study of 61 cases of spontaneous canine epistaxis (1998 to 2001). J Small Anim Pract 2008,49:191-196.

42. Gould DJ, Murphy K, Rudorf H, Crispin SM. Canine monocytic ehrlichiosis presenting as acute blindness 36 months after importation into the UK. J Small Anim Pract 2000,41:263265.

43. Leiva M, Naranjo C, Pena MT. Ocular signs of canine monocytic ehrlichiosis: a retrospective study in dogs from Barcelona, Spain. Vet Ophthalmol 2005,8:387-393.

44. Komnenou AA, Mylonakis ME, Kouti V, Tendoma L, Leontides L, Skountzou E, Dessiris A, Koutinas AF, Ofri R. Ocular manifestations of natural canine monocytic ehrlichiosis (Ehrlichia canis): a retrospective study of 90 cases. Vet Ophthalmol 2007,10:137-142.

45. Theodorou K, Leontides L, Siarkou VI, Petanides T, Tsafas K, Harrus S, Mylonakis ME. Synovial fluid cytology in experimental acute canine monocytic ehrlichiosis (Ehrlichia canis). Vet Microbiol 2016,177:224-227.

46. Gianopoulos A, Mylonakis ME, Theodorou K, Christopher MM. Quantitative and qualitative leukocyte abnormalities in dogs with experimental and naturally occurring acute canine monocytic ehrlichiosis. Vet Clin Pathol 2016,45:281-290.

47. Weiser MG, Thrall MA, Fulton R, Beck ER, Wise LA, Van Steenhouse JL. Granular lymphocytocis and hyperproteinemia in dogs with chronic ehrlichiosis. J Am Anim Hosp Assoc 1991,27:84-88.

48. Heeb HL, Wilkerson MJ, Chun R, Ganta RR. Large granular lymphocytosis, lymphocyte subset inversion, thrombocytopenia, dysproteinemia, and positive Ehrlichia serology in a dog. J Am Anim Hosp Assoc 2003,39:379-384.

49. Avery AC, Avery PR. Determining the significance of persistent lymphocytosis. Vet Clin North Am Small Anim Pract 2007,37:267-282.

50. Villaescusa A, Tesouro MA, García-Sancho M, Ayllón T, Rodríguez-Franco F, Sainz A. Evaluation of peripheral blood lymphocyte subsets in family-owned dogs naturally infected by Ehrlichia canis. Comp Immunol Microbiol Infect Dis 2012,35:391-396.

51. Frezoulis PS, Angelidou E, Karnezi D, Oikonomidis IL, Kritsepi-Konstantinou M, Kasabalis D, Mylonakis ME. Canine pancytopoenia in a Mediterranean region: a retrospective study of 119 cases (2005 to 2013). J Small Anim Pract 2017, in press (doi: 10.1111/jsap.12647).

52. Harrus S, Waner T, Aizenberg I, Foley JE, Poland AM, Bark H. Amplification of ehrlichial DNA from dogs 34 months after infection with Ehrlichia canis. J Clin Microbiol 1998,36:7376.

53. Harrus S, Waner T, Avidar Y, Bogin E, Peh H, Bark H. Serum protein alterations in canine ehrlichiosis. Vet Parasitol 1996,66:241-249.

54. Mylonakis ME, Kritsepi-Konstantinou M, Dumler JS, Diniz PP, Day MJ, Siarkou VI, Breitschwerdt EB, Psychas V, Petanides T, Koutinas AF. Severe hepatitis associated with acute Ehrlichia canis infection in a dog. J Vet Intern Med 2010,24:633-638.

55. Shimada T, Ishida Y, Shimizu M, Nomura M, Kawato K, Iguchi K, Jinbo T. Monitoring C-reactive protein in beagle dogs experimentally inoculated with Ehrlichia canis. Vet Res Commun 2002,26:171-177. 
56. Rudoler N, Harrus S, Martinez-Subiela S, Tvarijonaviciute A, van Straten M, Ceron JJ, Baneth G, 2015. Comparison of the acute phase protein and antioxidant responses in dogs vaccinated against canine monocytic ehrlichiosis and naive-challenged dogs. Parasit Vectors 2015,8:175.

57. Karnezi D, Ceron JJ, Theodorou K, Leontides L, Siarkou VI, Martinez S, Tvarijonaviciute A, Harrus S, Koutinas CK, Pardali D, Mylonakis ME. Acute phase protein and antioxidant responses in dogs with experimental acute monocytic ehrlichiosis treated with rifampicin. Vet Mic 2016,184:59-63.

58. Meinkoth JH, Ewing SA, Cowell RL, Dawson JE, Warner CK, Mathew JS, Bowles M, Thiessen AE, Panciera RJ, Fox C. Morphologic and molecular evidence of a dual species ehrlichial infection in a dog presenting with inflammatory central nervous system disease. $\mathrm{J}$ Vet Intern Med 1998,12:389-393.

59. Mylonakis ME, Koutinas AF, Billinis C, Leontides LS, Kontos V, Papadopoulos O, Rallis T, Fytianou A. Evaluation of cytology in the diagnosis of acute canine monocytic ehrlichiosis (Ehrlichia canis): a comparison between five methods. Vet Microbiol 2003,91:197-204.

60. Faria JL, Dagnone AS, Munhoz TD, Joao CF, Pereira WA, Machado RZ, Tinucci-Costa M. Ehrlichia canis morulae and DNA detection in whole blood and spleen aspiration samples. Rev Bras Parasitol Vet 2010,19:98-102.

61. Mylonakis ME, Borjesson DL, Leontides L, Siarkou VI, Theodorou K, Koutinas AF. Cytologic patterns of lymphadenopathy in canine monocytic ehrlichiosis. Vet Clin Pathol 2011,40:78-83.

62. Harrus S, Waner T. Diagnosis of canine monocytotropic ehrlichiosis (Ehrlichia canis): an overview. Vet J 2011,187:292-296.

63. Raskin RE, Mesick JB. Bone marrow cytologic and histologic biopsies: Indications, technique and evaluation. Vet Clin North Am Small Anim Pract 2012,42:23-42.

64. Mylonakis ME, Day MJ, Siarkou V, Vernau W, Koutinas AF. Absence of myelofibrosis in dogs with myelosuppression induced by Ehrlichia canis infection. J Comp Pathol 2010,142:328-331.

65. Harrus S, Alleman RA, Bark H, Mahan SM, Waner T. Comparison of three enzyme-linked immunosorbant assays with the indirect immunofluorescent antibody test for the diagnosis of canine infection with Ehrlichia canis. Vet Microbiol 2002,86:361-368.

66. Waner T, Harrus S, Jongejan F, Bark H, Keysary A, Cornelissen AW. Significance of serological testing for ehrlichial diseases in dogs with special emphasis on the diagnosis of canine monocytic ehrlichiosis caused by Ehrlichia canis. Vet Parasitol 2001,95:1-15.

67. Hegarty BC, de Paiva Diniz PP, Bradley JM, Lorentzen L, Breitschwerdt E. Clinical relevance of annual screening using a commercial enzyme-linked immunosorbent assay (SNAP 3Dx) for canine ehrlichiosis. J Am Anim Hosp Assoc 2009,45:118-124.

68. Gaunt SD, Corstvet RE, Berry CM, Brennan B. Isolation of Ehrlichia canis from dogs following subcutaneous inoculation. J Clin Microbiol 1996,34:1429-1432.

69. McBride JW, Corstvet RE, Gaunt SD, Boudreaux C, Guedry T, Walker DH. Kinetics of antibody response to Ehrlichia canis immunoreactive proteins. Infect Immun 2003,71:25162524.

70. Bartsch RC, Greene RT. Post-therapy antibody titers in dogs with ehrlichiosis: follow-up study on 68 patients treated primarily with tetracycline and/or doxycycline. J Vet Intern Med 1996,10:271-274.

71. Theodorou K, Mylonakis ME, Siarkou VI, Leontides L, Koutinas AF, Koutinas CK, Kritsepi-Konstantinou M, Batzias G, Flouraki E, Eyal O, Kontos V, Harrus S. Efficacy 
of rifampicin in the treatment of experimental acute canine monocytic ehrlichiosis. J Antimicrob Chemother 2013,68:1619-1626.

72. Hegarty BC, Levy MG, Gager RF, Breitschwerdt EB, 1997. Immunoblot analysis of the immunoglobulin $\mathrm{G}$ response to Ehrlichia canis in dogs: an international survey. J Vet Diagn Invest 9, 32-38.

73. Suksawat J, Hegarty BC, Breitschwerdt EB. Seroprevalence of Ehrlichia canis, Ebrlichia equi, and Ehrlichia risticii in sick dogs from North Carolina and Virginia. J Vet Intern Med 2000,14:50-55.

74. O'Connor TP, Hanscom JL, Hegarty BC, Groat RG, Breitschwerdt EB. Comparison of an indirect immunofluorescence assay, western blot analysis, and a commercially available ELISA for detection of Ehrlichia canis antibodies in canine sera. Am J Vet Res 2006,67:206210.

75. Stich RW, Rikihisa Y, Ewing SA, Needham GR, Grover DL, Jittapalapong S. Detection of Ehrlichia canis in canine carrier blood and in individual experimentally infected ticks with a p30-based PCR assay. J Clin Microbiol 2002,40:540-546.

76. Baneth G, Harrus S, Ohnona FS, Schlesinger Y. Longitudinal quantification of Ehrlichia canis in experimental infection with comparison to natural infection. Vet Microbiol 2009,136:321-325.

77. Iqbal Z, Rikihisa Y. Application of the polymerase chain reaction for the detection of Ehrlichia canis in tissues of dogs. Vet Microbiol 1994,42:281-287.

78. Wen B, Rikihisa Y, Mott JM, Greene R, Kim HY, Zhi N, Couto GC, Unver A, Bartsch R. Comparison of nested PCR with immunofluorescent-antibody assay for detection of Ehrlichia canis infection in dogs treated with doxycycline. J Clin Microbiol 1997,35:18521855.

79. Mylonakis ME, Siarkou VI, Leontides L, Bourtzi-Hatzopoulou E, Kontos VI, Koutinas AF. Evaluation of a serum-based PCR assay for the diagnosis of canine monocytic ehrlichiosis. Vet Microbiol 2009,138:390-393.

80. Harrus S, Kenny M, Miara L, Aizenberg I, Waner T, Shaw S. Comparison of simultaneous splenic sample PCR with blood sample PCR for diagnosis and treatment of experimental Ehrlichia canis infection. Antimicrob Agents Chemother 2004,48:4488-4490.

81. Gal A, Loeb E, Yisaschar-Mekuzas Y, Baneth G. Detection of Ehrlichia canis by PCR in different tissues obtained during necropsy from dogs surveyed for naturally occurring canine monocytic ehrlichiosis. Vet J 2008,175:212-217.

82. Schaefer JJ, Needham GR, Bremer WG, Rikihisa Y, Ewing SA, Stich RW. Tick acquisition of Ehrlichia canis from dogs treated with doxycycline hyclate. Antimicrob Agents Chemother 2007,51:3394-3396.

83. Eddlestone SM, Diniz PP, Neer TM, Gaunt SD, Corstvet R, Cho D, Hosgood G, Hegarty B, Breitschwerdt EB. Doxycycline clearance of experimentally induced chronic Ehrlichia canis infection in dogs. J Vet Intern Med 2007,21:1237-1242.

84. Schaefer JJ, Kahn J, Needham GR, Rikihisa Y, Ewing SA, Stich RW. Antibiotic clearance of Ehrlichia canis from dogs infected by intravenous inoculation of carrier blood. Ann N Y Acad Sci 2008,1149:263-269.

85. McClure JC, Crothers ML, Schaefer JJ, Stanley PD, Needham GR, Ewing SA, Stich RW. Efficacy of a doxycycline treatment regimen initiated during three different phases of experimental ehrlichiosis. Antimicrob Agents Chemother 2010,54:5012-5020.

86. Schulz BS, Hupfauer S, Ammer H, Sauter-Louis C, Hartmann K. Suspected side effects of doxycycline use in dogs-a retrospective study of 386 cases. Vet Rec 2011,169:229. 
87. Neer TM, Eddlestone SM, Gaunt SD, Corstvet RE. Efficacy of enrofloxacin for the treatment of experimentally induced Ehrlichia canis infection. J Vet Intern Med 1999,13:501504.

88. Eddlestone SM, Neer TM, Gaunt SD, Corstvet R, Gill A, Hosgood G, Hegarty B, Breitschwerdt EB. Failure of imidocarb dipropionate to clear experimentally induced Ehrlichia canis infection in dogs. J Vet Intern Med 2006,20:840-844.

89. Rudoler N, Baneth G, Eyal O, van Straten M, Harrus S. Evaluation of an attenuated strain of Ehrlichia canis as a vaccine for canine monocytic ehrlichiosis. Vaccine 2012,31:226-233.

90. Branger S, Rolain JM, Raoult D. Evaluation of antibiotic susceptibilities of Ebrlichia canis, Ehrlichia chaffeensis, and Anaplasma phagocytophilum by real-time PCR. Antimicrob Agents Chemother 2004,48:4822-4828.

91. Bajwa J, Charach M, Duclos D. Adverse effects of rifampicin in dogs and serum alanine aminotransferase monitoring recommendations based on a retrospective study of 344 dogs. Vet Dermatol 2013,24:570-575, e135-576.

92. Dumler JS, Madigan JE, Pusterla N, Bakken JS. Ehrlichioses in humans: epidemiology, clinical presentation, diagnosis, and treatment. Clin Infect Dis 2007, Suppl 1:S45-51.

93. Ismail N, McBride JW. Tick-borne emerging infections ehrlichiosis and anaplasmosis. Clin Lab Med 2017,37:317-340.

94. Mylonakis ME, Siarkou VI, Koutinas AF. Myelosuppressive canine monocytic ehrlichiosis (Ehrlichia canis): an update on the pathogenesis, diagnosis and management. Isr J Vet Med 2010,65:129-135.

95. Fourie JJ, Stanneck D, Luus HG, Beugnet F, Wijnveld M, Jongejan F. Transmission of Ehrlichia canis by Rhipicephalus sanguineus ticks feeding on dogs and on artificial membranes. Vet Parasitol 2013,197:595-603.

96. Jongejan F, de Vos C, Fourie JJ, Beugnet F. A novel combination of fipronil and permethrin (Frontline Tri-Act ${ }^{\circledR} /$ Frontect ${ }^{\circledR}$ ) reduces risk of transmission of Babesia canis by Dermacentor reticulatus and of Ehrlichia canis by Rhipicephalus sanguineus ticks to dogs. Parasit Vectors 2015,8:602.

97. Jongejan F, Crafford D, Erasmus H, Fourie JJ, Schunack B. Comparative efficacy of oral administrated afoxolaner (NexGard $\left.{ }^{\mathrm{TM}}\right)$ and fluralaner $\left(\right.$ Bravecto $\left.^{\mathrm{TM}}\right)$ with topically applied permethrin/imidacloprid (Advantix (®)) against transmission of Ehrlichia canis by infected Rhipicephalus sanguineus ticks to dogs. Parasit Vectors 2016,9:348.

98. Burgio F, Meyer L, Armstrong R. A comparative laboratory trial evaluating the immediate efficacy of fluralaner, afoxolaner, sarolaner and imidacloprid + permethrin against adult Rhipicephalus sanguineus (sensu lato) ticks attached to dogs. Parasit Vectors 2016,9:626.

99. Davoust B, Keundjian A, Rous V, Maurizi L, Parzy D. Validation of chemoprevention of canine monocytic ehrlichiosis with doxycycline. Vet Microbiol 2005,107:279-283. 


\section{MONOCITNA ERLIHIOZA PASA: AKTUELNOST U DIJAGNOSTICI I TRETMANU}

\section{MYLONAKIS Mathios E., THEODOROU Konstantina N.}

Monocitna erlihioza pasa (CME) je globalno rasprostranjeno obolenje koje prenose krpelji. Izazivač je Ehrlichia canis, gram-negativna, obligatno intracelularna, pleomorfna bakterija roda Ehrlichia, koja inficira monocite, makrofage i limfocite i pri tome formira morulu, tj. intracitoplazmatske agregate bakterija koji su okruženi membranom. Posle inkubacionog perioda koji traje od 8 do 20 dana, tok infekcije može da se podeli u akutnu, subkliničku i hroničnu fazu pri čemu se ove faze teško razlikuju samo na osnovu kliničkih ispitivanja. Tipično, ishod akutnog toka bolesti je ozdravljenje u kliničkom smislu pri čemu inficirana životinja ulazi u subkliničku fazu tokom koje nema simptoma ili su oni veoma slabo izraženi uz blage poremećaje hematoloških parametara. Imunokompetentni psi mogu da eliminišu uzročnika tokom akutne ili subakutne faze. Međutim, kod izvesnog broja pasa bolest prelazi u hroničan tok koji karakterišu aplastična pancitopenija i visok stepen mortaliteta usled septikemije i/ili krvarenja. U radu je ukratko opisana patogeneza monocitne erlihioze pasa uz detaljno opisana i analizirana najnovija saznanja koja se odnose na dijagnozu i tretman ovog ozbiljnog obolenja pasa. 